\title{
РАЗДЕЛЕНИЕ МЕТИЛОВЫХ ЭФИРОВ ВЫСШИХ ЖИРНЫХ КИСЛОТ МЕТОДОМ ПРЕПАРАТИВНОЙ ГАЗОВОЙ ХРОМАТОГРАФИИ
}

\section{II. Препаративное разделение}

T. SAKS, N. SAMEL, A. JAGOMAGI, A. IVANOV. KORGEMATE RASVHAPETE METUOLESTRITE LAHUTAMINE PREPARATIIVSE GAASIKROMATOGRAAFIA MEETODIL. II. PREPARATIIVNE ERALDAMINE

T. SAKS, N. SAMEL, A. JAGOMAGI, A. IVANOV. PREPARATIVE PURIFICATION OF METHYL ESTERS OF HIGHER FATTY ACIDS BY GAS CHROMATOGRAPHY. II. PREPARATIVE SEPARATION

Целью препаративной газохроматографической (ПГХ) очистки некоторых метиловых эфиров высших жирных кислот (МЭ ЖК) являлось получение названных МЭ ЖК со степенью чистоты свыше $90 \%$ - для дальнейшего их использования в качестве стандартов и снятия спектров. Әксперименты по ПГХ-разделению и очистке проводились в разреженной атмосфере газа-носителя ['] со смесью «линол», содержащей метиловые эфиры пальмитиновой $(16: 0)$, стеариновой $(18: 0)$, олеиновой $(18: 1)$, линолевой $(18: 2)$ и линоленовой $(18: 3)$ кислот (табл. 1$)$, а также с метиловым эфиром арахидоновой кислоты $(20: 4)$, выделенной из липидов (табл. 2). Аппаратура для ПГХ-разделения: хроматограф Хром-31 KZ с подключенным к нему (последовательно к ловушке) вакуумным насосом ВН-461 M.

Параметры опытов по ПГХ-разделению смеси «линол» и очистке МЭ арахидоновой кислоты приведены в табл. 3 .

В табл. 1 даны результаты выделения ПГХ чистых МЭ ненасыщенных ЖК из смеси «линол». Для очистки МЭ линоленовой кислоты до 99,3\% было достаточно одного этапа очистки. Для очистки МЭ линоле-

таблица 1

\begin{tabular}{|c|c|c|c|c|c|c|}
\hline \multirow{3}{*}{$\begin{array}{l}\text { Наименование соединений } \\
\text { (по порядку их выхода) }\end{array}$} & \multicolumn{6}{|c|}{ Содержание МЭ ЖК, \% } \\
\hline & \multirow{2}{*}{$\begin{array}{c}\text { В на- } \\
\text { чаль- } \\
\text { ной } \\
\text { пробе }\end{array}$} & \multicolumn{3}{|c|}{ I этап разделення } & \multicolumn{2}{|c|}{$\begin{array}{c}\text { II этап } \\
\text { разделения }\end{array}$} \\
\hline & & I фp. & II фp. & III фp. & I фp. & II фp. \\
\hline $\begin{array}{l}\text { МЭ пальмитиновой кислоты } \\
\text { МЭ стеариновой кислоты } \\
\text { МЭ олеиновой кислоты. } \\
\text { МЭ линолевой кислоты } \\
\text { МЭ линоленовой кислоты }\end{array}$ & $\begin{array}{r}5,6 \\
5,2 \\
22,7 \\
14,5 \\
52,4\end{array}$ & $\begin{array}{r}5,0 \\
84,0 \\
11,0 \\
-\end{array}$ & $\begin{array}{r}\overline{-} \\
4,0 \\
95,8 \\
0,2\end{array}$ & $\begin{array}{r}\overline{-} \\
0,1 \\
0,6 \\
99,3\end{array}$ & $\begin{array}{r}\overline{2,9} \\
96,1 \\
1,0 \\
-\end{array}$ & $\begin{array}{r}- \\
0,4 \\
99,6 \\
-\end{array}$ \\
\hline
\end{tabular}


Результаты препаративной очистки МЭ арахидоновой кислоты

Наименование веществ

(по порядку их выхода)

Содержание МЭ ЖК, \%

\begin{tabular}{|c|c|c|c|}
\hline (по порядку их выхода) & $\begin{array}{l}\text { в началь- } \\
\text { ной пробе }\end{array}$ & $\begin{array}{l}\text { I разде- } \\
\text { ление }\end{array}$ & $\begin{array}{l}\text { II разде- } \\
\text { ление }\end{array}$ \\
\hline $\begin{array}{l}\text { МЭ пальмитиновой кислоты } \\
\text { МЭ олеиновой и линолевой кислоты } \\
\text { МЭ арахидоновой кислоты } \\
\text { Неидентифицированные компоненты }\end{array}$ & $\begin{array}{r}6,3 \\
47,7 \\
7,2 \\
38,8\end{array}$ & $\begin{array}{r}2,3 \\
29,6 \\
49,6 \\
18,5\end{array}$ & $\begin{array}{r}\overline{0} \\
07,1 \\
2,0\end{array}$ \\
\hline
\end{tabular}

Параметры ПГХ-разделения МЭ ЖК

\begin{tabular}{|c|c|c|}
\hline Параметры & $\begin{array}{c}\text { ПГХ-разделение смеси } \\
\text { «линол» }\end{array}$ & $\begin{array}{c}\text { ПГХ-очистка МЭ ара- } \\
\text { хидоновой кислоты }\end{array}$ \\
\hline Длина колонки & $3.5 \mu$ & $2 \mu$ \\
\hline Внутр. диам. колонки & $10 \mathrm{MM}$ & $10 M \mu$ \\
\hline Твердый носитель & Хроматон- $N-A W$ & Динохром-II \\
\hline & 0,4-0,63 мм & 0,315-0,5 $\mathrm{MM}$ \\
\hline Жидкая фаза & $\begin{array}{c}\text { ПЭГ-20 } м \text { (10\% от веса } \\
\text { твердого носителя) }\end{array}$ & $\begin{array}{l}\text { Гептафениловый эфир (7\% } \\
\text { от веса твердого носителя) }\end{array}$ \\
\hline Температура, ${ }^{\circ} \mathrm{C}$ & & \\
\hline $\begin{array}{l}\text { колонки } \\
\text { испарителя }\end{array}$ & 235 & 255 \\
\hline $\begin{array}{l}\text { испарителя } \\
\text { катарометра }\end{array}$ & $\begin{array}{l}400 \\
300\end{array}$ & $\begin{array}{l}400 \\
290\end{array}$ \\
\hline $\begin{array}{l}\text { катарометра } \\
\text { распределительного крана }\end{array}$ & $\begin{array}{l}300 \\
300\end{array}$ & $\begin{array}{l}290 \\
260\end{array}$ \\
\hline ловушек & -60 & -60 \\
\hline $\begin{array}{l}\text { Вводимая доза } \\
\text { Давление газа-носителя (Не) }\end{array}$ & $60 \mu \kappa \Omega$ & от 200 до 600 мкл \\
\hline $\begin{array}{l}\text { на выходе из колонки } \\
\text { Уровень улавливания }\end{array}$ & $\begin{array}{l}4,2 \text { мм рт. } c T \text {. } \\
\text { не менее } 92 \%\end{array}$ & $\begin{array}{l}3,9 \text { мм рт. ст. } \\
\text { не менее } 90 \%\end{array}$ \\
\hline
\end{tabular}

вой кислоты до $99,6 \%$ и МЭ олеиновой кислоты до 96,1\% потребовалась дополнительно вторая очистка. В результате очистки ПГХ МЭ арахидоновой кислоты (табл. 2), проводившейся в два этапа, был получен светло-желтый маслянистый продукт, степень чистоты которого, определенная газохроматографическим методом, составила 97,1\% .

\section{Выводы}

1. Экспериментально доказана возможность препаративного газохроматографического разделения смеси МЭ ЖК в условиях разреженной атмосферы газа-носителя.

2. Установлено, что в разреженной атмосфере газа-носителя лучшие результаты получены в опытах с полимерными стационарными фазами, летучесть которых практически не зависит от давления в колонке.

\section{Л И Т Е Р А Т У Р А}

1. С акс Т., Иванов А., С амель А. Разделение метиловых эфиров высших жирных кислот методом препаративной газовой хроматографин. I. Предварительные опыты. - Изв. АН ЭССР, Хим., 1978, т. 27, № 3, с. 207-208. 